\title{
O Processo de Humanização como Ferramenta para Melhoria da Qualidade do Serviço
}

\author{
Almeida, Jose Jonathas Albuqueque de; Sousa, Elaine Freitas de; Tovar, Juliana \\ Eller; Rocha, Silmara Alves Moreira; Cavalcante, Juliana Brito; Santos, Monick \\ Forte; Silva, Zenaide Nunes da
}

Escola de Saude Publica do Estado do Ceara — pazpelavida@yahoo.com.br

É notório que o ambiente de trabalho é complexo e compõe diferentes aspectos distintos, trazendo para o ser humano certas realizações profissionais e conquistas a partir do trabalho exercido. Porém, sabe-se ainda que, o ambiente de trabalho junto com os serviços prestados gera com muita frequência nos profissionais envolvidos neste processo, o sentimento de individualidade, concorrência, enfado, desgaste emocional e emotivo, cansaço, desmotivação e desvalorização do mesmo, em decorrência de uma rotina cotidiana e enfadonha por se tornar rotineira. o objetivo deste trabalho é demonstrar a dimensão e relevância do processo de humanização na melhoria da qualidade do serviço e fortalecimento de sua utilização no ambiente de trabalho. Metodologia desta pesquisa é do tipo exploratório conservativa de caráter bibliográfico, realizada em livros, artigos científicos que dispõem de dados e informações comprovadas mediante pesquisa. a valorização do profissional, partindo da valorização de características subjetivas, que envolvem o processo de humanização pode produzir uma melhoria de qualidade no ambiente de trabalho e serviço diretamente prestado, através do reconhecimento dos diferentes sujeitos, com suas particularidades, autonomia e protagonismo coletivamente $e$ individualmente, mapeamento e interação dos fatores encontrados no serviço de trabalho, segurança do trabalhador e a disposição do mesmo na excursão e realização de suas atividades, fortalecimento do trabalho em equipe e maior vínculo institucional de forma ágil e resolutiva. o processo de humanização é uma ferramenta fundamental que serve para criar condições melhores e humanas para os trabalhadores e serviços, fortalecendo e estabelecendo vínculos e valorização dos diferentes sujeitos e elementos, refletindo na melhoria da qualidade do serviço diretamente e indiretamente quando desenvolvido. de acordo com os resultados das pesquisas realizadas sobre o assunto, o processo de humanização deve existir no interior das instituições e serviços para que seja possível atingir os índices satisfatórios de dimensões distintas e empenho de um serviço com qualidade, eficiência e eficácia.

Almeida, Jose Jonathas Albuqueque de; Sousa, Elaine Freitas de; Tovar, Juliana Eller; Rocha, Silmara Alves Moreira; Cavalcante, Juliana Brito; Santos, Monick Forte; Silva, Zenaide Nunes da. O Processo de Humanização como Ferramenta para Melhoria da Qualidade do Serviço. In: Anais do Congresso Internacional de Humanidades \& Humanização em Saúde [= Blucher Medical Proceedings, num.2, vol.1]. São Paulo: Editora Blucher, 2014. ISSN 2357-7282

DOI 10.5151/medpro-cihhs-10818 